\title{
Research on the Allocation of Cash Flow Rights and Control Rights in Venture Capital Financing Contract ${ }^{*}$
}

\author{
Yunfei Li ${ }^{1,2}$, Zongfang Zhou ${ }^{1}$ \\ ${ }^{1}$ School of Management and Economics, University of Electronic Science and Technology of China, Chengdu, China \\ ${ }^{2}$ School of Mathematics and Information, China West Normal University, Nanchong, China \\ Email: liyunfei80@126.com,Zhouzf@uestc.edu.cn
}

Received October 19, 2011; revised November 28, 2011; accepted December 27, 2011

\begin{abstract}
In view of the allocation of cash flow rights and control rights in venture capital firms, a financing contract model is set up by introducing the entrepreneur's self-owned capital in this paper. This paper analyzes the affecting factors and mechanism to the allocation of cash flow rights and control rights, shows the relationship between cash flow rights and control rights, gives the bargain intervals of the entrepreneur and the venture capitalist about the allocation of cash flow rights and control rights. It is shown that the more the entrepreneur's self-owned capital and the higher the venture capitalist's evaluation of the venture project and the ability of the entrepreneur, the fewer cash flow rights and control rights the venture capitalist will want; the relationship between cash flow rights and control rights of the venture capitalist is complementary but not corresponding, so the result provides a theoretical explanation for Kaplan and Stromberg's empirical researches about the disproportion between cash flow rights and control rights in venture capital firms.
\end{abstract}

Keywords: Venture Capital Firms; Financing Contract; Self-Owned Capital; Cash Flow Rights; Control Rights

\section{Introduction}

At the beginning of the founding of a venture capital firm, the entrepreneur (hereinafter referred to as EN) usually has only human capital such as patents, proprietary technology and insufficient self-owned capital. Therefore, the venture capital is extremely important resource for the new entrepreneurial firm. In order to get venture capital, The EN may conceal unfavorable information on his own, leading the venture capitalist (hereinafter referred to as VC) to face high uncertainty of the new entrepreneurial firm, high asymmetric information and other issues in investment, this is bound to affect the financing success rate. How to design rational and effective venture capital financing contract, to attract and motivate the VC's capital are the problems to be solved in the entrepreneurial process for the venture capital firm.

The core problem of the venture capital firm is the allocation of cash flow rights and control rights [1,2]. The former is the ultimate goal of the VC's investment, the latter is a security system which helps the VC to get cash flow rights safely, the allocation of these two rights are decided by the purposes of both investment and financing

\footnotetext{
*This research has been supported by National Natural Science Foundation of China (No.70971015).

Yunfei Li, PhD, liyunfei80@126.com;

Zongfang Zhou, Professor, Zhouzf@uestc.edu.cn
}

involvements. In the beginning, facing wealth constraints, besides allocating corresponding cash flow rights to the VC, the EN must actively relinquish part of control rights to the VC in order to attract the VC's capital (though this may reduce the EN's own private benefits), this is actually the signal about project quality the EN passes to the VC by transfer of control rights [3]; The purpose of the VC investment the venture capital firm is to obtain high capital benefits, but he also faces high risks. Therefore, in addition to requiring some cash flow rights, he will also ask for part of control rights to control the risks due to asymmetric information to a certain degree.

Aghion and Bolton [1] discussed the allocation of enterprise rights between the EN and the VC when the EN in the case of wealth constraint. They believed that control rights is an integrated whole, can only be wholly owned or completely transferred by one party. Dewatripont and Tirole [3] thought that in the venture capital financing contract of the venture capital firm, the only performance-based monetary incentives (cash flow rights) are far from enough for the $\mathrm{VC}$, giving the $\mathrm{VC}$ a certain degree of control rights must be taken into consideration, and the reason of the $\mathrm{VC}$ using control rights to intervene the management of the venture capital firm is derived from cash flow rights given by venture capital financing contract. Berglof [4] considered that when the situation of the venture capital firm is good, the VC will own all of 
the cash flow rights, and the EN have control rights, in this way, the EN can obtain compensation for his private benefits when bargaining with the new buyer in the future; when the condition of venture capital firms is not good, then the VC will have control rights, he can get corresponding compensation through the equity dilution which resulted from the new buyer's intervening the company. Kaplan and Stromberg's empirical researches show [5]: cash flow rights are disproportionate with control rights in the venture capital firm, and their researches also confirmed Berglof's theoretical findings. Based on the study of Aghion and Bolton, Hellmann [6] discussed under what circumstances is the EN willing to take the initiative to transfer control rights to the VC. His conclusion is: at the beginning of the founding of an entrepreneurial firm, facing wealth constraints, the EN had to balance between equity and control rights, and in order to obtain relatively more equity, the EN will give up some control rights. Gebhard and Schmidt [7] combined the allocation of control rights in the venture capital firm and financial instruments to discuss the allocation of control rights and the investment efficiency of the firm when the VC uses the three different financial instruments, that is, debt, equity and convertible debt. In their model, cash flow rights and control rights of the venture capital firm are combined through financial contracts, which provide a way of thinking on the study of corporate governance efficiency from the perspective of venture capital financing contracts.

In recent years, some Chinese scholars also aimed at the allocation of rights in the optimal venture capital financing contract. An shi and Wangjian [8,9] studied the problems such as control rights' allocation, transfer and structure in venture capital financing contracts. Based on Aghion and Bolton's researches [1], Yan zhi-xiong and Fei fang-yu [10] used the incomplete contract theory to discuss the three forms of the allocation of control rights in venture capital financing contract: entrepreneurs control, contingent control and investors control. Furthermore, they analyzed the problems of financing conditions and the allocation of profits in these cases. Wang lei and Dang xing-hua [11] built the dynamic game model of the structure of control rights in venture capital backed new hightech firms, compared the applicable conditions of contingent control and joint control, and analyzed the influence factors of the structure of control rights in venture capital firms. Wang sheng-cou and Zeng yong [12] applied the framework of incomplete contracts analyzing the allocation of liquidation rights, replacement rights and convertible securities in venture capital firms. They show that the conflicts of interest between the VC and the EN can be resolved through the combination of convertible securities and liquidation rights and replacement rights. $\mathrm{Li}$ jian-jun and Fei fang-yu [13] considered the VC can im- plement the effective ex-post control by the convertible preferred equity, and cash flow rights from the convertible preferred equity are the efficient implementation mechanisms for the VC's ex-ante control rights. Wu bin and Huang ming-feng [14] choose 168 venture capital firms which are from 2006-2008 Shenzhen small and mediumsized listed companies, to testify the influences on the allocation of control rights based on firms' performance and characteristics of human resources. The results show there is a negative correlation between the shares proportion of venture capital and firms' performance; there is a negative correlation between the allocation of control rights and the level of senior managers' education.

However, the existing researches ignored that the EN's self-owned capital may affect the allocation of cash flow rights and control rights at the beginning of the founding of venture capital firms; and they can't prove Kaplan and Stromberg's [5] empirical results that controls rights are disproportionate with cash flow rights in venture capital firms. Because the allocation of cash flow rights and control rights is sure to be influenced by the EN's initial wealth, therefore, we will do a further research on the allocation of cash flow rights and control rights in venture capital financing contract based on introducing the EN's self-owned capital, hoping it can endogenously explain the relationship between the two kinds of rights and the mechanism which influences the allocation of the two kinds of rights.

\section{The Model of the Financing Contract}

\subsection{The Assumptions of the Model}

Assuming that at the beginning of the founding of a venture capital firm, the EN exclusively has an innovative project that requires an initial capital $I(I>0)$, and the EN has the self-owned capital $I_{1}\left(0<I_{1}<I\right)$; The EN offers a financing contract to the VC who is risk neutral, expecting to get venture capital $I_{2}\left(I_{2}=I-I_{1}\right)$. Suppose the VC thinks the probability that the EN is high ability is $p_{1}\left(0<p_{1}<1\right)$, and thinks the probability that the project is good idea is $p_{2}\left(0<p_{2}<1\right)$. Because of the asymmetric information and the overconfidence of the EN [15], the EN is more optimistic than the VC in the judgments of the quality of the project and his ability. Therefore, suppose the EN thinks the probability that he is high ability is $q_{1}\left(0<p_{1}<q_{1}<1\right)$, and thinks the probability that the project is good idea is $q_{2}\left(0<p_{2}<q_{2}<1\right)$. Suppose The VC finances the project with the combination of debt and equity $[16,17]$, including debt capital is $x\left(0<x<I_{2}\right)$, equity capital is $y\left(0<y<I_{2}\right)$, obviously $I_{2}=x+y$. Assuming the risk-free interest rate is

$I_{2}=x+y$, after the negotiation between the EN and the $\mathrm{VC}$, the EN offers the debt capital interest $r\left(r>r_{0}\right)$ to $\mathrm{VC}$, and the VC gets the equity claim $\beta(0<\beta<1)$. 
As the venture capital firm has the features of high risk, high uncertainty and so on, when the financing contract is signed, the VC will ask to get some control rights to conduct supervision and management over the firm, in this way to control the investment risks as much as possible, and the EN is also willing to relinquish part of control rights to the $\mathrm{VC}$, because the transfer of part of control rights can weaken the VC's participation conditions. Reference to Tirole's point of view [18], we assume that the proportion of control rights that the $\mathrm{EN}$ relinquishes to the VC is $\lambda(0<\lambda<1)$ in the initial financing contract. Dyck and Zingales [19], Hellmann [6], Dessí [20] thought that the benefits of control rights are existed in the process of investment, they can be divided into the monetary benefits of control rights and the non-monetary benefits of control rights. The non-monetary benefits of control rights, that is to say, the private benefits are only owned by the EN. For the above reasons, we assume that when the EN gets all control rights, his private benefits are $B(B>0)$, and when the EN relinquishes part of control rights $\lambda$ to the $\mathrm{VC}$, his private benefits will be reduced to $(1-\lambda) B$.

To succeed in the venture capital firm, it must be built on a combined basis which includes the innovative projects, the excellent business and management talents. Therefore, suppose the firm can be successful if and only if the project is a good idea and the EN is of high ability. If the venture capital firm is ultimately successful, the income will be $R(R>(1+r) x)$; if there is any bad signal about performance in the implementation process, the VC will use his control rights to liquidate the venture capital firm, the purpose of doing that is to protect his own investments through control rights, thereby reducing his investment risks. The VC's control rights will affect the final liquidation value of the venture capital firm, specifically, when liquidation happens, the more control rights the VC owns, the greater the protective effect will be over the investment. In order to simplify the calculation, we assume the liquidation value of the venture capital firm is $\lambda L\left(0<\lambda L<I_{2}\right)$ when the project fails.

\subsection{Arrangement of the Liquidation Preference}

When the project fails, the arrangement of the liquidation preference is the first issue to be resolved in the initial financing contract. As the VC invested debt capital $x$ to the firm, when the liquidation value of the venture capital firm satisfies $0<\lambda L<x<I_{2}$, the VC is clearly has the liquidation preference. Therefore, in order to make the discussion meaningful, we further assume that: If the project fails, the liquidation value of the venture capital firm satisfies $x<\lambda L<I_{2}$. The paper is to discuss the arrangement of the liquidation preference from the following two cases.
1) The VC has the liquidation preference.

Under this circumstance, when the venture capital firm is liquidated, we suppose the contract offers the debt capital interest $r_{1}$ to the $\mathrm{VC}$, then, the expected utilities of the $\mathrm{VC}$ and the EN are given by:

$$
\begin{aligned}
U_{C 1}= & p_{1} p_{2}\left\{\beta\left[R-\left(1+r_{1}\right) x\right]+\left(1+r_{1}\right) x\right\} \\
& -\left(1-p_{1} p_{2}\right)\left(I_{2}-\lambda L\right)-I_{2}\left(1+r_{0}\right) \\
U_{E 1}= & q_{1} q_{2}\left\{(1-\beta)\left[R-\left(1+r_{1}\right) x\right]\right\}-\left(1-q_{1} q_{2}\right) I_{1} \\
& +(1-\lambda) B-I_{1}\left(1+r_{0}\right)
\end{aligned}
$$

2) The EN and the VC all have the liquidation preference.

Under this circumstance, when the venture capital firm is liquidated, we suppose the contract offers the debt capital interest $r_{2}$ to the VC, then, the expected utilities of the $\mathrm{VC}$ and the EN are given by:

$$
\begin{aligned}
U_{C 2}= & p_{1} p_{2}\left\{\beta\left[R-\left(1+r_{2}\right) x\right]+\left(1+r_{2}\right) x\right\} \\
& -\left(1-p_{1} p_{2}\right)[y-\beta(\lambda L-x)]-I_{2}\left(1+r_{0}\right) \\
U_{E 2}= & q_{1} q_{2}\left\{(1-\beta)\left[R-\left(1+r_{2}\right) x\right]\right\}-\left(1-q_{1} q_{2}\right) \\
& {\left[I_{1}-(1-\beta)(\lambda L-x)\right]+(1-\lambda) B-I_{1}\left(1+r_{0}\right) }
\end{aligned}
$$

In order to analyze the EN how to allocate the liquidation preference in the financing contract, we only need to compare the influences of two liquidation rights' allocation strategy over the EN's expected utility. To do this, we calculate:

$$
\begin{aligned}
U_{E 1}-U_{E 2}= & q_{1} q_{2}(1-\beta)\left(r_{2}-r_{1}\right) x \\
& -\left(1-q_{1} q_{2}\right)(1-\beta)(\lambda L-x)
\end{aligned}
$$

When the EN offers financing contract to the VC, he only needs to satisfy the VC's participation conditions. So, we get the following $r_{1}$ and $r_{2}$ by letting $U_{C 1}=0$ and $U_{C 2}=0$,

$$
\begin{aligned}
& r_{1}=\frac{\left(1-p_{1} p_{2}\right)\left(I_{2}-\lambda L\right)+I_{2}\left(1+r_{0}\right)-p_{1} p_{2} \beta R}{p_{1} p_{2}(1-\beta) x}-1 \\
& r_{2}=\frac{\left(1-p_{1} p_{2}\right)[y-\beta(\lambda L-x)]+I_{2}\left(1+r_{0}\right)-p_{1} p_{2} \beta R}{p_{1} p_{2}(1-\beta) x}-1
\end{aligned}
$$

Using (5), (6) and (7) we have:

$$
U_{E 1}-U_{E 2}=\frac{\left(q_{1} q_{2}-p_{1} p_{2}\right)(1-\beta)(\lambda L-x)}{p_{1} p_{2}}>0
$$

We get the following Result 1 from (8).

Result 1: At the beginning of the founding of the venture capital firm, despite the EN has invested his selfowned capital, when the project fails, the EN will benefit from his own proceeding, voluntarily relinquish the liq- 
uidation preference to the VC.

In fact, by comparing (6) with (7), we have

$$
r_{2}-r_{1}=\frac{\left(1-p_{1} p_{2}\right)(\lambda L-x)}{p_{1} p_{2} x}>0
$$

Therefore, when the innovation project fails, the EN will initiatively take the strategy of relinquishing the liquidation preference to the VC. This strategy provides protection for the VC's venture capital to some extent, attracting the VC's venture capital, making the debt capital interest the VC requires be reduced, thereby reducing the financing costs of the venture capital firm.

\subsection{The Participation Conditions of the EN and the VC}

According to the Result 1, the participation condition that the EN will look for venture capital and start the innovative project is given by

$$
\begin{aligned}
U_{E 1}= & q_{1} q_{2}\{(1-\beta)[R-(1+r) x]\}-\left(1-q_{1} q_{2}\right) I_{1} \\
& +(1-\lambda) B-I_{1}\left(1+r_{0}\right) \geq 0
\end{aligned}
$$

The participation condition that the VC will invest his venture capital to the venture capital firm is given by

$$
\begin{aligned}
U_{C 1}= & p_{1} p_{2}\{\beta[R-(1+r) x]+(1+r) x\}-\left(1-p_{1} p_{2}\right) \\
& \cdot\left(I_{2}-\lambda L\right)-I_{2}\left(1+r_{0}\right) \geq 0
\end{aligned}
$$

From (10), We have:

$$
\begin{aligned}
r & \leq r^{E N} \\
& =\frac{q_{1} q_{2}(1-\beta) R-\left(1-q_{1} q_{2}\right) I_{1}+(1-\lambda) B-I_{1}\left(1+r_{0}\right)}{q_{1} q_{2}(1-\beta) x}
\end{aligned}
$$

$\beta \leq \beta^{E N}$

$=\frac{q_{1} q_{2}[R-(1+r) x]-\left(1-q_{1} q_{2}\right) I_{1}+(1-\lambda) B-I_{1}\left(1+r_{0}\right)}{q_{1} q_{2}[R-(1+r) x]}$

$\lambda \leq \lambda^{E N}$

$=\frac{q_{1} q_{2}(1-\beta)[R-(1+r) x]-\left(1-q_{1} q_{2}\right) I_{1}+B-I_{1}\left(1+r_{0}\right)}{B}$

From (11), We have:

$$
\begin{aligned}
r & \geq r^{V C} \\
& =\frac{\left(1-p_{1} p_{2}\right)\left(I_{2}-\lambda L\right)+I_{2}\left(1+r_{0}\right)-p_{1} p_{2} \beta R}{p_{1} p_{2}(1-\beta) x}-1
\end{aligned}
$$

$$
\begin{aligned}
\beta & \geq \beta^{V C} \\
& =\frac{\left(1-p_{1} p_{2}\right)\left(I_{2}-\lambda L\right)+I_{2}\left(1+r_{0}\right)-p_{1} p_{2}(1+r) x}{p_{1} p_{2}[R-(1+r) x]}
\end{aligned}
$$

$$
\begin{aligned}
& \lambda \geq \lambda^{V C} \\
& =\frac{\left(2+r_{0}-p_{1} p_{2}\right) I_{2}-p_{1} p_{2}[\beta R+(1-\beta)(1+r) x]}{\left(1-p_{1} p_{2}\right) L}
\end{aligned}
$$

According to the analysis of the participation conditions of the EN and the VC, we get the intervals about the allocation of cash flow rights and control rights.

The financing of the venture capital firm may succeed if $r \in\left[r^{V C}, r^{E N}\right], \beta \in\left[\beta^{V C}, \beta^{E N}\right], \lambda \in\left[\lambda^{V C}, \lambda^{E N}\right]$. In fact, the three intervals are the bargain intervals about the allocation of cash flow rights and control rights in the initial financing contract, if the VC and the EN negotiate according to the three intervals, the allocation of cash flow rights and control rights may be resolved.

\subsection{The Analysis of Affecting Factors}

We have proposed the bargain intervals about the allocation of cash flow rights and control rights in Section 2.3, next, we will discuss the factors that affect boundaries of these intervals. Firstly, we will analyze the factors that affect the EN's financing strategy.

From (12), we will get $\partial r^{E N} / \partial I_{1}<0, \partial r^{E N} / \partial \lambda<0$, so, we have the following Result 2.

Result 2: 1) The more self-owned capital the EN invests, the less debt capital interest he is willing to relinquish to the $\mathrm{VC}$;

2) The more control rights the VC gains, the less debt capital interest the EN is willing to relinquish to the VC.

From (13), we will get $\partial \beta^{E N} / \partial I_{1}<0, \partial \beta^{E N} / \partial \lambda<0$, so, we have the following Result 3.

Result 3: 1) The more self-owned capital the EN invests, the less equity claim he is willing to relinquish to the VC;

2) The more control rights the VC gains, the less equity claim the EN is willing to relinquish to the VC.

From (14), we will get $\partial \lambda^{E N} / \partial I_{1}<0, \partial \lambda^{E N} / \partial \beta<0$ $\partial \lambda^{E N} / \partial r<0, \partial \lambda^{E N} / \partial\left(q_{1} q_{2}\right)>0$, so, we have the following Result 4.

Result 4: 1) The more self-owned capital the EN invests, the less control rights he is willing to relinquish to the $\mathrm{VC}$;

2) The more equity claim the VC gains, the less control rights the $\mathrm{EN}$ is willing to relinquish to the $\mathrm{VC}$;

3) The more debt capital interest the VC gains, the less control rights the EN is willing to relinquish to the $\mathrm{VC}$;

4) The higher the EN estimates the possibility of the new entrepreneurial firm's success, the more control rights he is willing to relinquish to the VC.

From Results 2 to 4, we know that at the beginning of the founding of the venture capital firm, if the more selfowned capital the EN invests, then he is more reluctant to relinquish more cash flow rights and control rights to the VC. In other words, if the EN's wealth constraint is seri- 
ous, then he is willing to relinquish the VC more cash flow rights or control rights in order to attract the VC's investment of venture capital. In addition, the relationship between cash flow rights and control rights that the EN is willing to relinquish to the VC is complementary, specifically, the more control rights the EN is willing to relinquish to the VC, the less cash flow rights the EN is willing to relinquish to the VC. In particular, if the higher the EN evaluates his creativity and ability $\left(q_{1}, q_{2}\right.$ are larger), then the more he will believe that he has the ability of making the venture capital firm successful. Therefore, the EN is willing to relinquish the VC more control rights, such a strategy can reduce the VC's concern of investment risks, which to some extent, reduce the VC's requirements of cash flow rights, and the EN can get more monetary return. It can explain that in the venture capital practice, why those EN who have full confidence of their own creativity and ability are willing to give the VC more control rights to supervise themselves, but are very stingy in terms of relinquishing the cash flow rights.

Next we analyze the factors that affect his investment strategies from the VC's viewpoint (note $I_{2}=I-I_{1}$ ). From (15), we get $\partial r^{V C} / \partial I_{1}<0, \partial r^{V C} / \partial \lambda<0$, $\partial r^{V C} / \partial\left(p_{1} p_{2}\right)<0$ (see the Appendix), so, we have the following Result 5 .

Result 5: 1) The more self-owned capital the EN invests, the less debt capital interest the VC is going to require;

2) The more control rights the VC gains, the less debt capital interest he is going to require;

3) The higher the VC estimates the possibility of the venture capital firm's success, the less debt capital interest he is going to require.

From (16), we will get $\partial \beta^{V C} / \partial I_{1}<0, \partial \beta^{V C} / \partial\left(p_{1} p_{2}\right)$ $<0, \partial \beta^{V C} / \partial \lambda<0$ (see the Appendix), so, we have the following Result 6 .

Result 6: 1) The more self-owned capital the EN invests, the less equity claim the $\mathrm{VC}$ is going to require;

2) The more control rights the VC gains, the less equity claim he is going to require;

3) The higher the VC estimates the possibility of the venture capital firm's success, the less equity claim he is going to require.

From (17), we will get $\partial \lambda^{V C} / \partial I_{1}<0, \partial \lambda^{V C} / \partial \beta<0$, $\partial \lambda^{V C} / \partial r<0, \partial \lambda^{V C} / \partial\left(p_{1} p_{2}\right)<0$ (see the Appendix), so, we have the following Result 7.

Result 7: 1) The more self-owned capital the EN invests, the less control rights the VC is going to require;

2) The more equity claim the VC gains, the less control rights he is going to require;

3) The more debt capital interest the VC gains, the less control rights he is going to require;

4) The higher the VC estimates the possibility of the venture capital firm's success, the less control rights he is going to require.

From Results 5 to 7, we know that at the beginning of the founding of the venture capital firm, if the more selfowned capital the EN invests, the higher the VC estimates the possibility of the venture capital firm's success, then the VC is likely to reduce his requirements of gaining cash flow rights or control rights. In other words, if the EN's wealth constraint is serious, or the VC's expectation of the venture capital firm's success is not high, then the VC is willing to invest his venture capital on the basis of gaining more cash flow rights or control rights. In addition, the relationship between cash flow rights and control rights the VC requires is complementary, specifically, the more cash flow rights (or control rights) the VC requires, the less control rights (or cash flow rights) he will gain.

\section{The Analysis of the Results}

From the discussion in the Section 2.4, we conclude the self-owned capital the EN invested at the beginning of the founding of the venture capital firm and the VC's judgments on the possibility of the firm's success are two important factors that will affect the allocation of cash flow rights and control rights in the venture capital financing contract.

In fact, the self-owned capital the EN invested at the beginning of the founding of the venture capital firm has two effects: first, passing on the quality signal about the venture projects [21], and second, to a certain extent, guaranteeing the venture capital the VC invested. If the self-owned capital the EN invested at the beginning of the founding of the venture capital firm is relatively more, then the guaranteeing role is large and will reduce the VC's investment risks, therefore, cash flow rights and control rights the VC requires will be relatively less. Based on the above analysis, we argue that the most important role of the EN's self-owned capital is to weaken the VC's participation conditions. However, the more the EN's self-owned capital invested, the greater risks he will face. In view of this, at the beginning of the founding of the venture capital firm, the EN will balance the role of security and risks from his self-owned capital to choose the optimal amount of self-owned capital.

On the other hand, only in the case when the venture project is a good idea, and the EN is of high capacity, starting the project can have the chance to be successful. Therefore, if the VC's evaluation on the venture project's creativity and the EN's ability is high, then the VC will estimate that the possibility of the EN's effectively managing the venture capital firm and making the firm successful is high, which can reduce investment risks, the VC will correspondingly reduce the interference in business activities of the firm or the requirements of cash flow rights. This result is in match with the actual prac- 
tice in venture capital, before making investment decisions, the VC will, in particular, examine the potential market competitiveness of the venture capital firm's innovative projects and the human capital such as the personnel ability of the corporate management, such a review process aims at effectively control the investment risks.

The traditional firm theory holds the view that cash flow rights and control rights of an enterprise are corresponding, having more control rights equals to get more cash flow rights. However, our theoretical study shows that in the field of venture capital, cash flow rights and control rights the VC gained are in a complementary rather than a corresponding relationship. To some extent, the research validates Kaplan and Stromberg's empirical results about the disproportion between cash flow rights and control rights in venture capital firms. Therefore, in venture capital firms, the separation characteristics of cash flow rights and control rights are significantly different from the allocation characteristics in traditional firms.

\section{Conclusions}

At the beginning of the founding of a venture capital firm, in order to solve the financing problems, the EN will attract the VC's capital investment through some incentives such as by providing some of his self-owned capital. Therefore, we include the EN's self-owned capital into the financing contract of the venture capital firm, and on this basis, study the allocation of cash flow rights and control rights in the venture capital firm. The results show that:

1) At the beginning of the founding of a venture capital firm, the self-owned capital the EN invests, the EN and the VC's judgments of the firm's success possibility will affect the allocation of cash flow rights and control rights in venture capital financing contract. Specifically, the more self-owned capital the EN invests, the less cash flow rights and control rights the $\mathrm{VC}$ will require, that is to say, the EN's self-owned capital is able to weaken the VC's participation conditions, this is helpful for realizing the EN's financing target; if the higher the VC evaluates the project's creativity and the EN's ability, then the less cash flow rights and control rights the VC will require, that is to say, the creative venture projects and the EN who is of high capacity are easy to get support from venture capital; if the higher the EN assesses his creativity and ability, then he is willing to relinquish relatively more control rights to the VC, but will correspondingly reduce the relinquishment of cash flow rights.

2) At the beginning of the founding of a venture capital firm, cash flow rights and control rights the VC gains are complementary. Specifically, the more cash flow rights (or control rights) the VC requires, then the less control rights (or cash flow rights) he will gain.
In the venture capital financing contract, the allocation of cash flow rights and control rights should be the outcome of the negotiation between the VC and the EN. Therefore, the three bargain intervals of the EN and the VC about the allocation of cash flow rights and control rights are derived out in this paper.When signing the contract, if the VC and the EN negotiate according to the three intervals, the allocation of cash flow rights and control rights will be effectively resolved.

We are mainly aiming at studying the allocation of cash flow rights and control rights at the beginning of the founding of venture capital firms. Another important feature of venture capital is stage investment, with the signals which are related to the management process of the venture capital firm revealed, the EN and the VC will renegotiate about the allocation of cash flow rights and control rights based on the new information obtained [22]. Therefore, the dynamic allocation of cash flow rights and control rights in venture capital firms need in-depth researches in the future.

\section{REFERENCES}

[1] P. Aghion and P. Bolton, “An Incomplete Contract Approach to Financial Contracting," Review of Economic Studies, Vol. 59, No. 3, 1992, pp. 473-494. doi: $10.2307 / 2297860$

[2] Y. Zeng, W. X Guo and D. W. Li, "Survey of Empirical Studies on Contracting and Governance of Venture Capital Investments,” Journal of Management Sciences in China, Vol. 11, No. 1, 2008, pp. 110-121. doi:10.2307/2118355

[3] M. Dewatripont and J. Tirole, “A Theory of Debt and Equity: Diversity of Securities and Manager Shareholder Congruence," Quarterly Journal of Economics, Vol. 109, No. 3, 1994, pp. 1027-1054.

[4] E. Berglof, "A Control Theory of Venture Capital Finance," Journal of Law, Economics and Organization, Vol. 10, No. 4, 1994, pp. 247-267.

[5] S. Kaplan and P. Stromberg, "Financial Contracting Theory Meets the Real World: Evidence from Venture Capital Contract,” Review of Economic Studies, Vol. 70, No. 2, 2003, pp. 281-315. doi:10.1111/1467-937X.00245

[6] T. Hellmann, "The Allocation of Control Rights in Venture Capital Contract,” Rand Journal of Economics, Vol. 29, No. 1, 1998, pp. 57-76. doi:10.2307/2555816

[7] G. Gebhard and K. M. Schmidt, "Conditional Allocation of Control Rights in Venture Capital Finance,” 2006. http://papers.ssrn.com/sol3/papers.cfm

[8] S. An, J. Wang and L. He, "Allocation of Control Rights between Venture Capitalist and Entrepreneur by Game Theory," System Engineering Theory and Practice Academic Journal, Vol. 22, No. 12, 2002, pp. 81-87.

[9] S. An, J. Wang and L. He, "Study on Allocation Model of Control Rights in Venture Firms," Journal of Systems Engineering, Vol. 19, No. 1, 2004, pp. 38-44. 
[10] Z. X. Yan and F. Y. Fei, "Control Allocation in Firm Financings and Entrepreneur's Incentive," Economic Research Journal, Vol. 56, No. 2, 2007, pp. 111-122.

[11] L. Wang, X. H. Dang and L. P. He, "Research on the Selection and the Influencing Factors of Control Rights Structure in Venture Capital-backed New High-tech Firms Based on Incomplete Contract," Chinese Journal of Management Science, Vol. 17, No. 5, 2009, pp. 166-174.

[12] S. C. Wang and Y. Zeng, "Convertible Securities and Control Rights in Ventures Firm,” Journal of Systems Engineering, Vol. 25, No. 2, 2010, pp. 209-215,276.

[13] J. J. Li, F. Y. Fei and Z. L. Zheng, "Convertible Preferred Equity and Efficiency of Venture Capitalist Controlling -An Incomplete Contract Perspective," Journal of Management Sciences in China, Vol. 13, No. 2, 2010, pp. 41-49.

[14] B. Wu and M. F. Huang, "Firm Performance, Human Resources' Characteristics of Senior Managers and Control Right Allocation: Evidence from Small and Medium Board's Venture Enterprises in China," China Soft Science Magazine, Vol. 17, No. 4, 2011, pp. 161-174.

[15] A. C. Cooper, W. C. Dunkelberg and C. Y. Woo, "Entrepreneurs Perceived Chances for Success," Journal of Business Venturing, Vol. 3, No. 1, 1998, pp. 97-108.
[16] F. Cornelli and O. Yosha, "Stage Financing and the Role of Convertible Securities,” Review of Economic Studies, Vol. 70, No. 1, 2003, pp. 1-32. doi:10.1111/1467-937X.00235

[17] M. S. Klaus, "Convertible Securities and Venture Capital Finance,” Journal of Finance, Vol. 58, No. 3, 2003, pp. 1139-1166. doi:10.1111/1540-6261.00561

[18] T. Tirole, “Corporate Governance,” Economitrica, Vol. 69, No. 1, 2001, pp. 1-35. doi:10.1111/1468-0262.00177

[19] A. Dyck and L. Zingales, "Private Benefits of Control: An International Comparison,” Journal of Finance, Vol. 59, No. 2, 2004, pp. 537-600. doi:10.1111/j.1540-6261.2004.00642.x

[20] R. Dessí, "Venture Capitalists, Monitoring and Advising,” 2009. http://neeo.univ-tlse1.fr/2294/1/venturecapitalists.pdf

[21] E. Ramy and G. Arieh, "A Multi-period Game Theoretic Model of Venture Capitalist and Entrepreneurs," European Journal of Operational Research, Vol. 144, No. 3, 2003, pp. 440-453.

[22] J. Gu and Z. F. Zhou, "Termination Decision Analysis for Venture Capital Based on Signal Learning,” Chinese Journal of Management, Vol. 6, No. 10, 2009, pp. 1306-1312.

\section{Appendix}

Proof of $\partial r^{V C} / \partial\left(p_{1} p_{2}\right)<0, \partial \beta^{V C} / \partial\left(p_{1} p_{2}\right)<0$, $\partial \lambda^{V C} / \partial\left(p_{1} p_{2}\right)<0$

Proof: From (15), (16) and (17), we have

$$
\begin{gathered}
\frac{\partial r^{V C}}{\partial\left(p_{1} p_{2}\right)}=\frac{\lambda L-I_{2}-I_{2}\left(1+r_{0}\right)}{(1-\beta)\left(p_{1} p_{2}\right)^{2} x} \\
\frac{\partial \beta^{V C}}{\partial\left(p_{1} p_{2}\right)}=\frac{\lambda L-I_{2}-I_{2}\left(1+r_{0}\right)}{[R-(1+r) x]\left(p_{1} p_{2}\right)^{2}} \\
\frac{\partial \lambda^{V C}}{\partial\left(p_{1} p_{2}\right)}=\frac{I_{2}\left(1+r_{0}\right)-\beta R-(1-\beta)(1+r) x}{\left(1-p_{1} p_{2}\right)^{2} L} \\
=\frac{I_{2}\left(1+r_{0}\right)-\beta[R-(1+r) x]-(1+r) x}{\left(1-p_{1} p_{2}\right)^{2} L}
\end{gathered}
$$

Because $x<\lambda L<I_{2}, \quad R>(1+r) x$, we therefore obtain

$$
\partial r^{V C} / \partial\left(p_{1} p_{2}\right)<0, \partial \beta^{V C} / \partial\left(p_{1} p_{2}\right)<0 .
$$

From Equation (11), we obtain

$$
\begin{aligned}
& p_{1} p_{2}\{\beta[R-(1+r) x]+(1+r) x\}-\left(1-p_{1} p_{2}\right)\left(I_{2}-\lambda L\right) \\
& >I_{2}\left(1+r_{0}\right)
\end{aligned}
$$

Obviously, $\quad \beta[R-(1+r) x]+(1+r) x>I_{2}\left(1+r_{0}\right)$, we therefore obtain $\partial \lambda^{V C} / \partial\left(p_{1} p_{2}\right)<0$. 